ROCZNIKI TEOLOGICZNE

Tom LXVII, zeszyt $11-2020$

DOI: https://doi.org/10.18290/rt206711-6

ANNA ZELLMA

\title{
CREATIVITY OF RELIGION TEACHERS AS A DETERMINANT OF STUDENTS' CREATIVITY
}

\begin{abstract}
A bstract. The analyses undertaken in this paper aim to show the importance of the creativity of religion teachers for the development of their students' creativity in the course of religion lessons. The starting point is the thesis according to which the creativity of religion teachers is a determinant of students' creativity. Such an approach required the use of the analytic-synthetic method. The analysis included the available literature on the subject. Based on this, the identity of creative religion teachers was first characterized in a synthetic manner. Their personal characteristics and the substantive and methodological competence were identified. In this context, specific activities of religion teachers were analysed, which testify to their creativity and at the same time motivate students to engage in a multifaceted, creative activity. Particular emphasis was placed on the use of various forms of organization of students' work during religion lessons, methods, techniques and didactic aids. The questions posed not only by the teachers but also by the students were considered important. It was also observed that a creative religion teacher not only strives for external activation of students, but also supports them in discovering the values of the Gospel, their conversion and trusting in Christ. In their teaching and educational work, religion teachers need appropriate support, since they should continuously develop and learn, as well as improve their methodological skills.
\end{abstract}

Keywords: religion teacher; religion education; creativity; didactic; formation.

\section{INTRODUCTION}

The changes taking place in the approach towards the teacher and his or her competences are nowadays focused on creativity. This is expressed, among others, by the standards of education preparing for the teaching pro-

AnNA Zellma, Prof. Dr Hab., University of Warmia and Mazury in Olsztyn, Faculty of Theology, Department of Pastoral Theology and Catechetics: address for correspondence: ul. Kardynała Stanisława Hozjusza 15, 11-041 Olsztyn, Poland; e-mail: anna.zellma@uwm.edu.pl; ORCID: https:// orcid.org/0000-0002-3612-3454. 
fession $^{1}$ and proposals in the field of general didactics ${ }^{2}$ and didactics of religious instruction. ${ }^{3}$ Furthermore, the fact of being a religion teacher in a modern Polish school also implies creative involvement. It requires commitment and liberation from existing patterns of thinking and educational behaviour. This calls for becoming an innovative religion teacher. ${ }^{4}$ The considerable amount of creative didactic and educational activity in religion lessons significantly determines the creativity of students. Unfortunately, in practice, the creativity of such teachers leaves much to be desired. This is confirmed by the results of sociological research, ${ }^{5}$ as well as by media debates, observations ${ }^{6}$ and press reports. $^{7}$ It appears that the theoretical knowledge acquired during studies and the first experience gained during practical training is not enough. Proper personal qualities are also required, including openness to change, the ability to broaden and deepen substantive and methodological knowledge, the commitment to develop professional competence and, above all, the ability to create and apply new solutions. A special focus is on the ability to think reflectively and to strive to create something new in teaching and educational practice. Only such religion teachers can stimulate the multifaceted activity of the students in the course of religion lessons, and at the same time encourage them to discover the values of the Gospel and support them in their conversion and trust in Christ. It can therefore be argued that the creativity of religion teachers is necessary to motivate students to take creative actions in the face of various educational events and to support them in their comprehensive

\footnotetext{
${ }^{1}$ Regulation of the Minister of Science and Higher Education of 25 July 2019 on the standards of education in preparation for the teaching profession, Dziennik Ustaw 2019, item 1450.

${ }^{2}$ See, e.g., Franciszek BEREŹNICKI, Dydaktyka szkolna dla kandydatów na nauczycieli (Kraków: Impuls, 2018).

${ }^{3}$ See, e.g., Marek Korgul, Dydaktyka dla katechetów (Świdnica: Usługi Poligraficzne Bogdan Kokot vel Kokociński, 2014); Stanisław ŁABENDOwicz, Dydaktyka katechezy (Radom: Instytut Naukowo-Wydawniczy “Spatium,” 2019).

${ }^{4}$ More on this subject can be found in Anna Zellma, "Innowacyjne inicjatywy pedagogiczne w środowisku szkolnym i parafialnym,” Studia Etckie 19, special issue (2017): 675-89.

${ }^{5}$ See, e.g., Witold JEDYNA, "Nauczanie religii w polskich szkołach - sukces czy porażka?" Poznańskie Studia Teologiczne 32 (2018): 207-28; Paweł MĄKOSA, “Tożsamość nauczycieli religii i ich opinie na temat wybranych aspektów edukacji religijnej w Polsce," Roczniki Teologiczno-Pastoralne, no. 1 (2009): 117-31.

${ }^{6}$ See, e.g., Dagmara GıUSZEK-SZAFraniec, "Nauczanie religii w szkole w Polsce - analiza wybranych debat medialnych," Politeja, no. 1 (2017): 265-82, doi:10.12797/Politeja.14.2017.46.11.

${ }^{7}$ See, e.g., Monika BiaŁKowsKa, "Katecheci - ludzie ze stali," Przewodnik Katolicki, March 10, 2019, accessed May 5, 2020, https://www.przewodnik-katolicki.pl/Archiwum/2019/PrzewodnikKatolicki-10-2019/Temat-numeru/Katecheci-ludzie-ze-stali.
} 
development, in the search for Christ, in the discovery of His selfless love and in the transformation of life, recognition of Christ as Lord and Savior.

In view of the above, the question concerning the importance of religion teachers' creativity in developing the creativity of students is justified. The answer to this question is relevant to the quality of didactic educational and catechetical activities undertaken by them during lessons. It raises the following questions: Who is a creative religion teacher? Which activities demonstrate his or her creativity during religion lessons? How does a creative religion teacher motivate students to act creatively? In search of answers, the most important literature proposals will be analysed. This will help to synthetically present the issues and draw important conclusions.

The following analyses are only an attempt to illustrate and show-from a theoretical perspective-creative religion teachers who foster their students' creativity. The starting point will be to present the identity of creative religion teachers and then to focus on developing students' creativity in religion lessons. The closing remarks will indicate the challenges for the initial and permanent formation of religion teachers, within which their creativity should be developed.

\section{THE IDENTITY OF A CREATIVE RELIGION TEACHER}

Creativity understood as a permanent ability to create and generate new and valuable ideas is an indispensable attribute in the work of the contemporary religion teacher. ${ }^{8}$ This is an extremely important quality, playing an essential role in education. It is manifested, among others, in the ability and readiness to develop students' creative attitudes. The creativity of religion teachers is directly related to innovation, i.e., the ability to put creative ideas into practice. It is often discussed in conjunction with methodological competence, which translates into multifaceted activation of students in religion lessons. ${ }^{9}$

At this point, it is worth recalling Marian Finke's valuable (and still valid) statements concerning the creativity of religion teachers. According to this excellent catechist and teacher, a pioneer of many methodological issues, creative religion teachers do everything to make their students aware of the process of

\footnotetext{
${ }^{8}$ More on this subject in, e.g., Anna Zellma, "Kreatywność w myśleniu i działaniu uczestników szkolnych lekcji religii - moda czy konieczność edukacyjna," Katecheta 51, nos. 7-8 (2007): 21-30.

${ }^{9}$ Ibid., see also Marian ZAJĄC, "Katechetyczne znaczenie postawy kreatywnej," Roczniki Pastoralno-Katechetyczne 60, no. 5 (2013): 99-114.
} 
teaching religion. ${ }^{10}$ They are capable of new, unconventional solutions to problems, as well as of behaviours going beyond routine and schematism. ${ }^{11}$ They are free from the compulsion to follow in the footsteps of others (e.g., authors of school curricula and textbooks) and from receiving and copying of ready-made methodological solutions. Creative religion teachers are characterized by rich imagination, ingenuity and perceptiveness. They reject the patterns established in the teaching of religion and ready-made patterns of practice during religion lessons. ${ }^{12}$ Not only are they familiar with the principles of didactic conduct and various methodological solutions, but they can also skilfully apply them in practice. ${ }^{13}$ Creative religion teachers do not deny the importance of didactics. However, they are able to reflectively apply the theory in practice. What is important is that they are also spontaneous. Nevertheless, this last feature does not imply randomness in action. On the contrary, it involves their ability to reflect before, in and on action. ${ }^{14}$

The didactic and educational work of creative religion teachers is characterised by active teaching and learning. It is based on basic didactic principles, particularly subjectivity, individualisation, dialogue and multidimensional involvement. The principle of loyalty to God and man is the foundation for creative religion teachers. ${ }^{15}$ The use of innovative solutions and constant experiments is not an end in itself. It serves the purpose of understanding the Christian message, explaining, interpreting, and recognizing the work of God in the life of the catechized. ${ }^{16}$

Creative religion teachers are aware that each student is different and that each educational situation is unique. Therefore, they prefer a personalised approach in the teaching and learning process and avoids a routine in action. Creative religion teachers stimulate students' cognitive curiosity and imagination, motivate them to think independently and seek creative solutions. They also create material products (e.g., calendars, props, teaching aids) together with their students. What is important is that they help their students to discover and develop their talents in a creative manner. ${ }^{17}$

\footnotetext{
${ }^{10}$ Marian FInKE, “Kreatywność w katechezie (I),” Katecheta 26, no. 3 (1982): 97.

${ }^{11}$ Ibid.

12 Ibid.

${ }^{13}$ Marian Finke, “Kreatywność w katechezie (IV),” Katecheta 26, no. 6 (1982): 258-59.

${ }^{14}$ More on this issue in Anna ZeLLMA, "Nauczyciel religii jako refleksyjny praktyk w realiach współczesnej szkoły," Katecheta 53, no. 9 (2009): 6-12.

${ }^{15}$ Cf. Kongregacja DS. Duchowieństwa, Dyrektorium ogólne o katechizacji (Poznań: Pallottinum, 1998), nos. 149, 152, 157.

${ }^{16}$ Ibid.

${ }^{17}$ Ibid.
} 
The subject matter and methodological competences of creative religion teachers go beyond the knowledge and skills acquired in the process of standard education in theological studies. Creative religion teachers appreciate creative activity more than the usual schemes and traditional teaching methods. ${ }^{18}$ They constantly improve their methodological tools and seek creative solutions. ${ }^{19}$ At the same time, they are open to real existential, social and cultural problems. They are able to establish and maintain links with students and animate the group "so that they feel the subject of their own decisions and actions." ${ }^{20}$ This also involves the ability to organize classes in such a way that "every [student] feels needed and valued," 21 and the atmosphere in the group stimulates the activity of its individual members and their personal development. $^{22}$

\section{DEVELOPING STUDENTS' CREATIVITY IN THE COURSE OF RELIGION LESSONS}

The creative activity of religion teachers is based on the knowledge of didactic principles, especially subjectivity, individualization and multidimensional and multifunctional mobilization of students. These principles play an important role in developing the creativity of learners. They emphasize the importance of respecting students' needs and interests, carrying out educational dialogue, negotiating meanings and constructing knowledge. ${ }^{23}$

Supporting students in developing their creativity requires the use of appropriate didactic and educational work strategies during religion lessons. Therefore, it is important to properly select and apply forms of organising students' activities as well as teaching methods, techniques and means. ${ }^{24}$ However, it is not just a matter of multifaceted and multifunctional mobilization of students in the course of religion lessons. An appropriate approach

\footnotetext{
${ }^{18}$ Marian FinKe, “Kreatywność w katechezie (II)," Katecheta 26, no. 4 (1982): 161-63.

${ }^{19}$ Ibid.

${ }^{20}$ Emilio AlBERICH, Katecheza dzisiaj. Podręcznik katechetyki fundamentalnej (Warsaw: Wydawnictwo Salezjańskie, 2003), 304.

${ }^{21}$ Ibid.

${ }^{22}$ Ibid.

${ }^{23}$ Cf. Marian FinKe, "Kreatywność w katechezie (III)," Katecheta 26, no. 5 (1982): 205-14; FINKE, "Kreatywność w katechezie (IV)," 258-62.

${ }^{24}$ Marian FinKe, Pedagogika wiary, comp. and ed. Feliks Lenort (Poznań: Papieski Wydział Teologiczny, Redakcja Wydawnictw, 1996), 56-57, 73-75.
} 
to teaching and educating activity of religion teachers is necessary and, in particular, their preferred style of teaching religion, professionalism, reflectiveness and passion. ${ }^{25}$ For instance, controlling the activity of students in the course of a religion lesson does not encourage the development of creativity. Students are only externally active. Their work in the lesson is subordinated to the objectives set by their religion teachers and the lesson units the latter have planned. Religion teachers only seemingly motivate students to be creative. This is because they decide how the lesson is going to run, and what, and in what order, actions are going to be taken by the students. The students' own activity is superficial and apparent. It is subordinated to the decision of a religion teacher. Students lose the sense of subjectivity and responsibility for their own actions. They experience that their activity is controlled and serves the didactic, educational and catechetical purposes assumed by the teacher. In this context, M. Finke's proposals are extremely relevant. The author aptly notes that "not every lesson must faithfully correspond to the plan, but all teaching must educate. If the catechist has sufficiently reflected on the lesson in terms of subject matter and didactics, he can at a given moment free himself from the constraints he has imposed himself in preparing it." ${ }^{26}$ This, in turn, encourages the creation of a space for free expression for students during religion lessons. Moreover, in the face of a problem that arises during classes, an unplanned event or questions from students, a creative religion teacher shows openness and readiness for educational dialogue. This allows students to express different points of view and to look for many ways to solve a specific problem. Learners may propose different solutions, some of which may be original or unique. They are also free to ask questions, express different opinions and their own perspective on life. ${ }^{27}$

Creative religion teachers give students the opportunity to talk about themselves, communicate their thoughts, desires, personal aspirations, and preferred values. ${ }^{28}$ They also teach the ability to respect the opinion of other people, take a look from the perspective of another person and listen actively. They also encourage cooperation in a group. The fact that students can reveal their individual attitude to the world around them, to God, the Gospel and the community of the Church, does not imply that religion teachers abandon presenting the unchanging content of faith and the principles of Christian life.

\footnotetext{
${ }^{25}$ Ibid.

${ }^{26}$ FinKe, "Kreatywność w katechezie (I)," 101.

${ }^{27}$ FINKE, Pedagogika wiary, 74.

${ }^{28}$ Ibid.
} 
On the contrary, in accordance with the principle of fidelity to God and man, referring to the experience and personal knowledge of the disciples and to Scripture, Tradition and the teaching of the Church, they seek a lasting relationship with the experience, knowledge, needs and interests of the students as well as with God and His revelation. ${ }^{29}$ They help their students to discover the content of the faith based on the Gospel and the teachings of the Church.

Developing the creativity of students, religion teachers consider it important to stimulate positive motivation. Therefore, every student experiences acceptance and approval from a creative religion teacher. Such a teacher can actively listen to students, is open to their questions and ideas, which he or she considers important and valuable. ${ }^{30}$ Creative religious teachers can appreciate any work and justify its value. In the course of such classes students feel safe. They have the courage to express their various opinions and views, often contrary to the Christian message and the teaching of the Church. Their religion teachers fully accept this situation. They encourage students to engage in dialogue. ${ }^{31}$ They create a space for their free expression. Students follow the instructions and requirements of their religion teacher not so much for fear of control and negative evaluation as for the expected success. In this way, participation in religion lessons becomes attractive for them. It stimulates and strengthens their positive motivation to acquire knowledge, and performs, above all, educational functions. A creative teacher of religion provides students with an opportunity for cooperation, dialogue, creative activity and strengthens their positive perception of themselves, the other person and the world around them. ${ }^{32}$

Content selection is also important for developing the creativity of students in religion lessons. Undoubtedly, religion teachers are obliged to follow the syllabus of teaching religion in accordance with the core curriculum. Moreover, as part of the pedagogical supervision, they are obliged to monitor the progress of the curriculum. While fulfilling this task, they can make reference to the students' interests and experiences. Importantly, they use not only closed content systems (and the convergent type tasks designed for such systems), which are to be learnt by the student, but also open divergent type

\footnotetext{
${ }^{29}$ For more on this subject, see Mieczysław MAJEWSKI, Antropologiczna koncepcja katechezy (Kraków: Poligrafia Salezjańska, 1995), 163.

${ }^{30}$ FInKe, Pedagogika wiary, 55-76.

${ }^{31}$ Ibid.

${ }^{32}$ Ibid.
} 
systems. ${ }^{33}$ Referring to students' various experiences and personal knowledge, religion teachers provide them with an opportunity to exchange views. Furthermore, they enable the verification of information obtained from various sources (e.g., in correlation with school education, from social networking sites, from peers). Creative religion teachers are up-to-date with novelties concerning the content of religious teaching, as well as other areas of general education, such as: the Polish language, history, knowledge of society, biology, music, art, philosophy, upbringing for family life. They are also familiar with the current interests and needs of students. They know what kind of music their students listen to, what they read, what programs, films and TV series they watch, what social networking sites they visit most frequently and what and why attracts their greatest interest in social media. This knowledge is essential for creative design and teaching of religion lessons.

The methodological tools used by creative religion teachers, as already noted above, mainly include various activating methods. Developing students' creativity requires the application of, among others, didactic and simulation games, problem and discussion methods and role-playing. ${ }^{34}$ Creative religion teachers use not only traditional but also modern teaching means, especially information and communication technologies. This permits a creative use of various sources of knowledge. Work in small groups and pairs is equally important. However, in such a planned organization of students' activities, the questions and instructions formulated by religion teachers are very important. ${ }^{35}$ They avoid questions and tasks that require only reproduction of information (e.g., How much..., Where..., What is the name of..., In which year...? Describe, name, list...). Instead, they often use open, problematic questions and tasks to activate students' thought processes (e.g., What should be done..., How can we..., Why should...? Give examples, arrange, justify..., Compare..., Design..., What can be the effects of..., What are the main causes..., What should be changed..., What are the similarities and differrences..., What is the meaning of..., How can you use in your everyday life the knowledge you have learned?). ${ }^{36}$ Consequently, in religion lessons conducted by a creative teacher, students often solve existential problems which

\footnotetext{
${ }^{33}$ For more on this subject, see Anna Zellma, Wielostronne aktywizowanie mtodzieży w szkolnym nauczaniu religii. Studum w świetle Programu nauczania religii katolickiej z 2001 roku (Olsztyn: Wydawnictwo Uniwersytetu Warmińsko-Mazurskiego w Olsztynie, 2006), 274-308.

${ }^{34}$ Ibid.

${ }^{35}$ Ibid.

${ }^{36}$ Ibid; cf. also Zbigniew BARCIŃSKI, “Jak dobrze postawić pytanie główne?” Katecheta 47, no. 3 (2003): 21-24; KORGUL, Dydaktyka dla katechetów, 285-92.
} 
have several possible solutions. They know that a religion teacher appreciates every activity.

Developing students' creativity also requires changing how rules and standards of behaviour in religion lessons are presented and enforced. It is important to establish common rules for students' behaviour in lessons, cooperation, discussion and creative activity. A teacher of religion can sign a contract with each student in which each party undertakes to follow certain rules.

In teaching religion, the above-described activities, although they clearly motivate students to develop their creativity, are not sufficient. Being an authentic educator and witness of faith forms an integral part of the mission that a creative religion teacher has to fulfil at school. He or she expected to have a strong faith and to live by it, to have confidence and love for God expressed in total trust, union with Christ and openness to the Holy Spirit, love of God's word and prayer, rooted in the community of the Church. ${ }^{37}$ The tasks of a creative religion teacher include not only stimulating students to think and act independently or to express themselves creatively but also to reflect and pray. Such a teacher is to demonstrate Christ and His gospel with his life and to initiate various activities leading the students to the meeting with Christ and conversion and encouraging Christian behaviour. ${ }^{38}$

\section{CONCLUDING REMARKS}

The issues analysed above give rise to specific challenges for the initial and permanent formation of religion teachers. They require changes in traditional forms and methods of organizing theological education as well as pedagogical and catechetical training. It is essential to support students of theology and religion teachers in acquiring the ability to creatively plan and act, and to improve their skills in terms of both teaching content and methodology. The creativity of students in religion lessons primarily depends on religion teachers. The curricula, student handbooks, methodological guidelines and teaching aids, however good they may be, cannot replace creative religion teachers. Such aids can only support them in their creative and reflective action, but it is the creativity of religion teachers that determines the creativity of their students.

\footnotetext{
${ }^{37}$ See detailed analyses in Marek MENDYK, "Katecheta - nauczyciel, wychowawca, świadek. Jego misja w warunkach nowej ewangelizacji," Perspectiva. Legnickie Studia Teologiczno-Historyczne 6, no. 1 (2007): 105-19.

${ }^{38}$ For more on this subject, see FINKE, Pedagogika wiary, 59-60, 65-67.
} 
Having in mind the good of students and the quality of teaching religion in Polish schools, it would be worthwhile to conduct qualitative research in the future using the method of narrative interview, biographical method and observation. Based on these findings it will be possible to draw conclusions about creativity in teaching religion and to make changes in the initial and permanent formation of religion teachers.

\section{BIBLIOGRAPHY}

Alberich, Emilio. Katecheza dzisiaj. Podręcznik katechetyki fundamentalnej. Warsaw: Wydawnictwo Salezjańskie, 2003.

BARCIŃSKI, Zbigniew. “Jak dobrze postawić pytanie główne?” Katecheta 47, no. 3 (2003): 21-24.

BEREŹNICKI, Franciszek. Dydaktyka szkolna dla kandydatów na nauczycieli. Kraków: Impuls, 2018.

BiAŁKOwSKA, Monika. "Katecheci - ludzie ze stali.” Przewodnik Katolicki, March 10, 2019. Accessed May 5, 2020. https://www.przewodnik-katolicki.pl/Archiwum/2019/Przewodnik-Katolicki10-2019/Temat-numeru/Katecheci-ludzie-ze-stali.

FINKE, Marian. "Kreatywność w katechezie (I).” Katecheta 26, no. 3 (1982): 97-101.

FINKE, Marian. "Kreatywność w katechezie (II).” Katecheta 26, no. 4 (1982): 161-64.

FINKE, Marian. "Kreatywność w katechezie (III).” Katecheta 26, no. 5 (1982): 205-14.

FINKE, Marian. "Kreatywność w katechezie (IV).” Katecheta 26, no. 6 (1982): 258-62.

FINKE, Marian. Pedagogika wiary. Compiled and edited by Feliks Lenort. Poznań: Papieski Wydział Teologiczny, Redakcja Wydawnictw, 1996.

GŁUSZEK-SZAFrAnIEC, Dagmara. "Nauczanie religii w szkole w Polsce - analiza wybranych debat medialnych.” Politeja, no. 1 (2017): 265-82. doi:10.12797/Politeja.14.2017.46.11.

JEDYNA, Witold. "Nauczanie religii w polskich szkołach - sukces czy porażka?" Poznańskie Studia Teologiczne 32 (2018): 207-28.

Kongregacja DS. DuchowIEŃSTwa, Dyrektorium ogólne o katechizacji. Poznań: Pallottinum, 1998.

KoRgul, Marek. Dydaktyka dla katechetów. Świdnica: Usługi Poligraficzne Bogdan Kokot vel Kokociński, 2014.

ŁaBENDOwiCZ, Stanisław. Dydaktyka katechezy. Radom: Instytut Naukowo-Wydawniczy "Spatium”, 2019.

Majewski, Mieczysław. Antropologiczna koncepcja katechezy. Kraków: Poligrafia Salezjańska, 1995.

MĄKOSA, Paweł. "Tożsamość nauczycieli religii i ich opinie na temat wybranych aspektów edukacji religijnej w Polsce.” Roczniki Teologiczno-Pastoralne, no. 1 (2009): 117-31.

MENDYK, Marek. "Katecheta - nauczyciel, wychowawca, świadek. Jego misja w warunkach nowej ewangelizacji." Perspectiva. Legnickie Studia Teologiczno-Historyczne 6 (2007): 1.

Rozporządzenie Ministra Nauki i Szkolnictwa Wyższego z dnia 25 lipca 2019 r. w sprawie standardu kształcenia przygotowującego do wykonywania zawodu nauczyciela [Regulation of the Minister of Science and Higher Education of 25 July 2019 on the standard of education in preparation for the teaching profession]. Dziennik Ustaw [Journal of Laws], 2019, item 1450. 
ZAJĄC, Marian. "Katechetyczne znaczenie postawy kreatywnej." Roczniki Pastoralno-Katechetyczne 60, no. 5 (2013): 99-114.

ZELLMA, Anna. "Nauczyciel religii jako refleksyjny praktyk w realiach współczesnej szkoły." Katecheta 53, no. 9 (2009): 6-12.

ZeLLMA, Anna. "Innowacyjne inicjatywy pedagogiczne w środowisku szkolnym i parafialnym." Studia Etckie 19, special issue (2017): 675-89.

ZELLMA, Anna. "Kreatywność w myśleniu i działaniu uczestników szkolnych lekcji religii - moda czy konieczność edukacyjna." Katecheta 51, nos. 7-8 (2007): 21-30.

Zellma, Anna. Wielostronne aktywizowanie młodzieży w szkolnym nauczaniu religii. Studium w świetle Programu nauczania religii katolickiej z 2001 roku. Olsztyn: Wydawnictwo Uniwersytetu Warmińsko-Mazurskiego w Olsztynie, 2006.

\section{KREATYWNOŚĆ NAUCZYCIELI RELIGII JAKO DETERMINANTA KREATYWNOŚCI UCZNIÓW}

Streszczenie

Analizy podjęte $\mathrm{w}$ artykule mają na celu ukazanie znaczenia kreatywności nauczyciela religii w rozwoju kreatywności uczniów w toku lekcji religii. Punktem wyjścia uczyniono tezę, że kreatywność nauczyciela religii stanowi determinantę kreatywności uczniów. Takie założenie wymagało zastosowania metody analizy i syntezy. Analizie poddano dostępną literaturę przedmiotu. $\mathrm{Na}$ tej podstawie - w sposób syntetyczny - najpierw scharakteryzowano tożsamość kreatywnego nauczyciela religii. Wskazano przy tym na jego cechy osobowe oraz kompetencje merytoryczne i metodyczne. W tym kontekście analizowano konkretne działania nauczyciela religii, które świadczą o jego kreatywności, a zarazem motywują uczniów do wielostronnej, twórczej aktywności. Wśród nich zwrócono uwagę na zastosowanie zróżnicowanych form organizacji pracy uczniów na lekcji religii, metody, techniki i środki dydaktyczne. Za istotne uznano pytania stawiane nie tylko przez nauczyciela, ale także przez uczniów. Zauważono też, że kreatywny nauczyciel religii dąży nie tylko do zewnętrznej aktywizacji uczniów, ale także wspiera ich w odkrywaniu wartości ewangelii, w nawróceniu i zawierzeniu Chrystusowi. W swojej pracy dydaktyczno-wychowawczej potrzebuje on odpowiedniej pomocy. Sam bowiem powinien nieustannie rozwijać się i formować oraz doskonalić warsztat metodyczny.

Słowa kluczowe: nauczyciel religii; edukacja religijna; kreatywność; dydaktyka; formacja. 